\title{
Mirosław Pawlak
}

Uniwersytet im. Adama Mickiewicza

Zakład Filologii Angielskiej, Kalisz.

\section{ROZWIJANIE AUTONOMII UCZNIA W PRACY Z UCZNIEM NIEZWYKLYM}

\begin{abstract}
Fostering autonomy and the exceptional language learner
Fostering learner autonomy is undoubtedly one of the most important goals of foreign language education in Poland, which is evidenced by the fact that it has been included in the current national curriculum, it figures prominently in virtually all available syllabi, and modern coursebooks include numerous elements intended to assist its implementation. It should be made clear, however, that the development of an autonomous approach to language learning is by no means an easy task, the success of which is to a large extent dependent on a particular student. Thus, the aim of the present paper is to demonstrate how autonomy can be effectively promoted in the case of exceptional learners, both such who are successful and such for whom learning a foreign language poses a formidable challenge.
\end{abstract}

\section{Wprowadzenie}

Pomimo faktu, że minęło już prawie trzydzieści lat od momentu publikacji przez Holca (1981) kluczowego i często cytowanego raportu opracowanego na zlecenie Rady Europy, w którym zdefiniował on autonomię jako umiejętność przejęcia odpowiedzialności za własną naukę, pojęcie to i oparte na nim podejście do edukacji językowej nie przestają cieszyć się ogromnym zainteresowaniem teoretyków, badaczy i metodyków. Świadczą o tym nie tylko wciąż bardzo liczne konferencje i opracowania naukowe poświęcone tej problematyce (np. Lamb i Reinders, 2007; Pemberton, Toogood i Barfield, 2010), ale również to, że tematyka ta coraz częściej znajduje swoje odzwierciedlenie w publikacjach przeznaczonych dla przyszłych i obecnych nauczycieli języków, czy to w postaci całościowych przewodników mających 
wspomagać skuteczne rozwijanie postaw i zachowań autonomicznych (np. Scharle i Schabó, 2000; Hurd i Murphy, 2005), czy to w oddzielnych rozdziałach w podręcznikach metodycznych (np. Hedge, 2000; Harmer, 2001) (patrz Benson, 2007). Tendencje te są również doskonale widoczne w Polsce, ponieważ także tutaj organizowane są konferencje, publikowane są monografie, prace zbiorowe oraz artykuły poświęcone autonomii w nauce języka obcego (np. Wilczyńska, 1999, 2002; Pawlak 2004, 2008a, w druku), opracowywane są narzędzia służące jej rozwijaniu, których przykładem mogą być wersje Europejskiego portfolio jezykowego przeznaczone dla różnych grup wiekowych, od przedszkolaków po osoby dorosłe, a problematyka promowania autonomii stanowi ważny element kształcenia nauczycieli języków obcych. Nie mniej ważne jest to, że wymóg rozwijania samodzielności uczniów wpisany został do obowiązującej podstawy programowej, co sprawia, że znajduje on odzwierciedlenie w opracowywanych programach nauczania i podręcznikach, w których normą jest obecność elementów służących promowaniu autonomii, takich jak samoocena i ocena wzajemna, listy umiejętności, trening strategiczny czy zachęcanie uczniów do gromadzenia wykonywanych prac.

Jeśli jednak przyjrzymy się otaczającej rzeczywistości edukacyjnej, to bardzo szybko stanie się jasne, że istnieje wyraźny rozdźwięk pomiędzy zaleceniami specjalistów i władz oświatowych a tym, co na co dzień można zaobserwować podczas lekcji języka obcego, przy czym sytuacja ta została odnotowana w licznych publikacjach (np. Bielska, 2008; Droździał-Szelest, 2008; Głowacka, 2008; Pawlak, 2008b, 2008c). Dla nikogo, kto chociaż trochę zna specyfikę polskiej szkoły nie jest bowiem tajemnica, że rozwijanie autonomii na pewno nie jest priorytetem dla zdecydowanej większości nauczycieli, którzy wolą koncentrować się na realizacji programu nauczania i przygotowaniu uczniów do nadchodzących egzaminów, a zamieszczane w podręcznikach zadania mające na celu stymulowanie samodzielności oraz wspomaganie treningu strategicznego są przez nich pomijane bądź też traktowane bardzo pobieżnie. Również wielu uczących się, i to niezależnie od etapu edukacyjnego, nie wydaje się być szczególnie zainteresowanych przejęciem odpowiedzialności za czynione postępy, ograniczając się do opanowania i ćwiczenia materiału wprowadzanego podczas lekcji, nie wykazując chęci do samodzielnego poszukiwania materiałów i sposobów efektywnej nauki, i polegając na ocenie dokonywanej przez nauczyciela. Choć taki stan rzeczy jest bez wattpienia wynikiem wielu różnych czynników (Komorowska, 2003), to jednym z kluczowych wydaje się być przekonanie o niemożności promowania autonomii w sytuacji, gdy uczniowie w tej samej klasie tak bardzo się od siebie różnia, zarówno pod względem poziomu opanowania danego języka, jak i osobowości, stylów uczenia się, stosowanych strategii, potrzeb czy preferencji. Dlatego też, celem niniejszego artykułu jest pokazanie, w jaki sposób rozwijanie postaw i zachowań o charakterze autonomicznym powinno uwzględniać tego typu specyfikę i niezwykłość uczących się, z zastrzeżeniem, że owa niezwykłość 
ogranicza się tutaj do różnych poziomów zaawansowania, a zasadniczy nacisk jest położony na możliwości zróżnicowania stosowanych technik w zależności od tego, czy mamy do czynienia z uczniem wybitnym, czy też nieco słabszym. Na początku przedstawione zostanie pokrótce samo pojęcie autonomii i zaprezentowane będą różnego rodzaju czynniki, które mogą w dużej mierze warunkować skuteczność podejmowanych przez nauczyciela działań służących jej rozwijaniu. Natomiast trzon publikacji stanowić będzie omówienie technik i zadań, które moga być zastosowane w celu stymulowania postaw i zachowań autonomicznych pośród uczących się na różnych poziomach zaawansowania.

\section{Geneza, definicje i charakterystyka autonomii}

Charakterystykę pojęcia autonomii warto rozpocząć od omówienia głównych przyczyn, dla których ten atrybut uczących się tak bardzo zyskał na popularności, a potrzeba jego rozwijania stała się jednym z nadrzędnych celów polityki językowej w większości krajów europejskich, przy czym będzie się ono tutaj ograniczać jedynie do najważniejszych z nich, tym bardziej, że szczegółowe przedstawienie genezy podejść o charakterze autonomicznym znaleźć można w wielu innych publikacjach (np. Michońska-Stadnik, 1996; Benson i Voller, 1997; Benson, 2011; Komorowska, 2003; Pawlak i in., 2006). W tym miejscu warto zwrócić uwagę na takie czynniki, jak zmiany społeczne i ideologiczne, które dokonywały się w latach 60. ubiegłego wieku i doprowadziły do powstania nowych grup, ruchów i inicjatyw, szczególnie w Stanach Zjednoczonych, a także radykalne propozycje reformy systemu edukacji, które wysunęli miedzy innymi Rogers (1969), Freire (1970) i Illich (1971), i które miały przede wszystkim na celu postawienie na pierwszym planie osoby ucznia i podejmowanych przez niego decyzji. Nie mniej istotne było pojawienie się konstruktywistycznych teorii uczenia się oraz pojęcia autoregulacji, które kładły nacisk na konieczność aktywnego zaangażowania się w proces przyswajania wiedzy i umiejętności oraz przewartościowanie poglądów na sam proces uczenia się języka obcego, co było związane z zanegowaniem koncepcji behawiorystycznej przy jednoczesnym zwróceniu uwagi na czynniki kognitywne, afektywne czy też społeczne. Dużą rolę odegrały również wyniki badań dotyczących cech i zachowań osób odnoszących sukces w nauce języka oraz różnic indywidualnych i stosowania strategii uczenia się, które jasno pokazały, że skuteczna nauka języka odbywać się może na wiele sposobów, a co za tym idzie niemożliwe jest uwzględnienie podczas lekcji indywidualnych preferencji i potrzeb uczniów. Wszystko to przyczyniło się do przewartościowania poglądów na role pełnione przez nauczyciela i uczniów, którego wyrazem było odejście od modelu przekazywania wiedzy i ukierunkowanie procesu nauczania na osobę ucznia, stwarzające mu jak najlepsze warunki do samodzielnego przyswajania umiejętności językowych oraz kreujące możliwości uczestniczenia we w miarę autentycznej komunikacji i przejęcia części odpowiedzialności za własną naukę. Warto również wspomnieć 
o zjawiskach, które nie były bezpośrednio związane z modyfikacją spojrzenia na sam proces uczenia się i były wynikiem procesów o charakterze globalnym, z jednej strony w pewien sposób wymuszając, a z drugiej znacząco ułatwiając autonomizację. Chodzi tutaj zarówno o lawinowo rosnącą liczbę osób uczących się języków, co uwidoczniło ograniczenia instytucji edukacyjnych i stanowiło impuls do poszukiwania alternatywnych sposobów nauki, jak i o zwiększającą się komercjalizację kształcenia językowego oraz rozwój technologii internetowej i informacyjnej, które doprowadziły do rozpowszechnienia nowatorskich rozwiązań w nauczaniu języków i promowania autonomii.

$\mathrm{Na}$ przestrzeni ostatnich trzydziestu lat nastapiły także daleko idace zmiany w samym sposobie rozumienia pojęcia autonomii, co musiało się przełożyć na modyfikację poglądów na skuteczne sposoby jej rozwijania w klasie językowej. Przede wszystkim, należy odnotować znacząca ewolucję, jakiej poddana została sama definicja autonomii, gdyż o ile Holec (1981) koncentruje się głównie na zachowaniach uczących się w odniesieniu do głównych etapów nauki, które są dowodem przejmowania przez nich odpowiedzialności, tj. na wyznaczaniu celów, doborze technik i strategii, monitorowaniu i dokonywaniu samooceny, to Little (1991) zwraca uwagę na psychologiczny wymiar tego typu działań, który jest związany ze zdolnością do bezstronności, krytycznej refleksji, podejmowania decyzji i niezależnego działania. Z kolei Benson (2001) definiuje autonomię w odniesieniu do stopnia kontroli nad różnymi aspektami procesu uczenia się, podkreślając, że związana jest ona nie tylko z podejmowanymi przez uczących się działaniami i czynnikami psychologicznymi, ale również decyzjami dotyczącymi treści i celów nauki. Kładzie on jednocześnie nacisk na społeczny i sytuacyjny wymiar postaw i zachowań o charakterze autonomicznym, ponieważ zakres kontroli nad wymienionymi powyżej elementami nie zależy tylko i wyłącznie od jednostki, ale raczej od umiejętności wspólnego podejmowania decyzji w ściśle określonych sytuacjach. Warto tutaj również wspomnieć o definicji zaproponowanej przez Dam (2002), która zwraca uwage na fakt, że autonomię należy rozważać nie tylko w kontekście zdolności do przejmowania odpowiedzialności za własną naukę, czy to w wymiarze określonych zachowań, czy mechanizmów psychologicznych, które umożliwiają podejmowanie takich właśnie działań, ale także chęci i gotowości uczących się do wykazywania postaw i zachowań o charakterze autonomicznym. Jest to o tyle istotne, że z łatwością można znaleźć uczniów, którzy moga, ale z różnych przyczyn wcale nie chcą stawać się bardziej samodzielnymi, bądź są niezwykle autonomiczni, gdy chodzi o pewne przedmioty szkolne, a ograniczają się tylko i wyłącznie do materiałów i zadań zaproponowanych przez nauczyciela w przypadku innych, choćby dlatego, że uważają je za mało potrzebne i przydatne.

Kolejną kwestią, nad którą należałoby się zastanowić są pewne dystynktywne cechy autonomii w nauce języków obcych, tym bardziej, że również tutaj nie brakuje nieporozumień i często bardzo rozbieżnych opinii. Przede wszystkim, jak wynika zresztą z zaprezentowanych powyżej definicji, 
autonomia jest obecnie uznawana za atrybut uczacych się, a nie, jak to miało miejsce wcześniej, sytuacji, w których odbywa się nauka języka (Dickinson, 1987). Oznacza to, że samo stworzenie okoliczności, w których uczący się muszą być samodzielni nie gwarantuje, że właśnie w taki sposób będą się oni zachowywać, choć oczywiście może to w jakimś stopniu sprzyjać autonomizacji. Trzeba sobie również zdawać sprawę $z$ faktu, że nieuprawnione byłoby kategoryczne stwierdzenie, iż uczniowie są lub nie są autonomiczni, ponieważ da się wyróżnić różne poziomy autonomii, co sprawia, że można być samodzielnym w bardzo różnym stopniu, a cecha ta ma charakter dynamiczny i podlega fluktuacjom w zależności od wielu czynników. Dla przykładu, Littlewood (1999) proponuje rozróżnienie pomiędzy autonomia proaktywnq, która podkreśla indywidualny wymiar nauki i pozwala uczącym się na samodzielne jej ukierunkowanie, i autonomiq reaktywna, gdzie cele nauki zostają określone przez nauczyciela, ale uczniowie mają swobodę w doborze metod i środków ich realizacji. Równie ważne jest to, że, niezależnie od poziomu, autonomia może się przejawiać na bardzo różne sposoby w zależności od czynników indywidualnych, takich jak wiek, wyznaczone cele czy motywacja, i kontekstualnych, takich jak chociażby omawiane treści czy rodzaj wykonywanego zadania (por. Little, 1991). Warto też pamiętać, że, wbrew temu co mogłoby się wydawać, autonomia jest nie tylko właściwością jednostki, tak jak ma to miejsce podczas nauki bez nadzoru nauczyciela, ale również grupy, gdyż, jak już wspomniano powyżej, wiąże się ona ze zmianą ról nauczyciela i ucznia w klasie szkolnej oraz zdolnością do wspólnego podejmowania decyzji, tak jak ma to miejsce podczas pracy w parach i małych grupach czy wykonywania zadań projektowych. Nie mniej ważne jest to, że choć większa samodzielność jest zazwyczaj utożsamiana $z$ wyższym poziomem zaawansowania, to relacja ta jest bardziej złożona, bo przecież można sobie łatwo wyobrazić osobę, która dopiero zaczyna uczyć się nowego języka i już od samego początku jest bardzo samodzielna, ale zapewne również taką, która dobrze posługuje się tym językiem, a jest jedynie w ograniczonym stopniu autonomiczna (Kumaravadivelu, 2003). Trzeba też podkreślić, że rozwijanie autonomii może być postrzegane jako sposób na zwiększenie efektywności nauki języka obcego (tzw. autonomia dla nauki jezykea) lub jako cel sam w sobie, ponieważ większa samodzielność ma przygotować uczących się do skutecznego funkcjonowania w wielu sferach życia (tzw. nauka jezylka dla autonomii). Zakres i sposób autonomizacji musi też uwzględniać specyfikę kulturową i ściśle z nią związane ograniczenia danego systemu edukacyjnego, choćby dlatego, że trudno byłoby oczekiwać, aby polscy uczniowie zachowywali się podczas lekcji w taki sam sposób jak ich amerykańscy rówieśnicy (Benson i Voller, 1997; Benson, 2001, 2007).

Omówienie pojęcia autonomii byłoby niepełnie bez przedstawienia cech i zachowań charakterystycznych dla ucznia autonomicznego, gdyż to właśnie one stanowią podstawowy wyznacznik samodzielności uczących się z punktu 
widzenia nauczyciela. Jedno $\mathrm{z}$ najbardziej znanych zestawień zaprezentował Boud (1988), który twierdzi, że uczniowie cechujący się wysokim poziomem autonomii wykazuja inicjatywę $\mathrm{w}$ takich obszarach jak określanie swoich potrzeb, wyznaczenie celów nauki, dobór odpowiednich technik i strategii, poszukiwanie źródeł, środków i materiałów, współpraca z innymi członkami grupy, identyfikacja problemów i samodzielne ich rozwiązywanie, wybór miejsca i czasu nauki, postrzeganie nauczyciela jako doradcy i przewodnika, a nie jako głównego źródła informacji i wskazówek, podejmowanie działań wykraczających poza wymagania szkolne, dokonywanie samooceny, uczenie się poza szkoła, decydowanie o tym, kiedy należy zakończyć naukę, refleksja nad procesem uczenia się oraz świadomość, że podejmowane decyzje mogą mieć wpływ nie tylko na osiagane w danej chwili wyniki, ale również na całe życie. Z kolei Legutke i Thomas (1991) koncentrują się na podstawowych umiejętnościach, jakie powinien posiadać samodzielny i niezależny uczeń, wskazując między innymi na zwracanie uwagi na jakość uczenia się, rejestrowanie postępów i rozróżnianie sposobów nauki, podejmowanie decyzji dotyczących poszczególnych etapów nauki i dobieranie odpowiednich środków, przejmowanie odpowiedzialności za zmianę wyznaczonych celów i uzasadnianie decyzji tego typu, skuteczną pracę zespołową i zaakceptowanie odpowiedzialności za jej wyniki oraz podejmowaną z własnej inicjatywy rzetelną samoocenę i zainteresowanie postępami innych członków grupy. Rzecz jasna, trudno oczekiwać, aby nawet bardzo autonomiczny uczący się wykazywał wszystkie takie cechy i zachowania w każdej sytuacji, bo, jak już wspomniano powyżej, autonomia może przejawić się w bardzo różny sposób w przypadku poszczególnych osób i uwarunkowań, a takie czynniki jak rodzaj zadania czy rozwijana sprawność językowa moga determinować to, czy i w jakim stopniu uczeń zechce być samodzielny.

\section{Rozwijanie autonomii a specyfika ucznia}

Jak pisze Harmer (2001: 335), „Niezależnie od tego jak dobry jest nauczyciel, uczniowie nigdy nie nauczą się języka - ani czegokolwiek innego - jeśli nie będą starali się uczyć nie tylko w klasie szkolnej, ale także poza nią. Język jest zbyt skomplikowany, aby uczniowie mogli się w klasie nauczyć wszystkiego, czego potrzebuja” (tłumaczenie autora). Jak wynika z tego cytatu, zdolność do przejęcia odpowiedzialności za własną naukę, jak również gotowość do podejmowania działań autonomicznych $\mathrm{w}$ dużej mierze warunkują sukces $\mathrm{w}$ nauce języka obcego i są po prostu nieodzowne w sytuacji, kiedy szkolny i pozaszkolny kontakt z jezzykiem docelowym jest czasami bardzo ograniczony, tak jak ma to miejsce w przypadku edukacji językowej w Polsce. Już sam ten fakt stanowi wystarczające uzasadnienie dla podejmowania kroków mających na celu stymulowanie postaw i zachowań autonomicznych, czy to poprzez włączanie odpowiednich treści do programów nauczania, zamieszczanie stosownych zadań 
w podręcznikach, zachęcanie uczących się do korzystania z dodatkowych narzędzi, takich jak na przykład Europejskie portfolio jesylkowe, czy też różne działania nauczyciela podczas lekcji. Specjaliści wskazują także na wiele innych, bardziej ogólnych powodów, dla których warto rozwijać autonomię. Zwracają na przykład uwagę na to, że postęp we wszystkich dziedzinach życia jest tak szybki, iż konieczne jest nabywanie wiedzy i umiejętności, także w odniesieniu do języków obcych, przez całe życie, najczęściej we własnym zakresie. Autonomia przekłada się na bardziej skuteczne przyswajanie języka, a uczeń, który przejmuje odpowiedzialność za własną naukę, ma większe szanse na opanowanie nie tylko wiedzy deklaratywnej, czyli reguł gramatycznych czy pojedynczych słów, ale również wiedzy proceduralnej, czyli umiejętności zastosowania form językowych w komunikacji. Nie mniej ważne jest to, że autonomia wpisuje się w rozwój indywidualny i społeczny jednostki, stanowi integralny element procesu uczenia się, czy to w przypadku języka obcego, czy innego przedmiotu, i umożliwia indywidualizację procesu dydaktycznego. Warto także podkreślić, że decyzja o podjęciu działań zmierzających do rozwijania autonomii może być korzystna dla samych nauczycieli, jako że motywuje ich ona do większego zaangażowania, stymuluje kreatywność, zachęca do poszukiwania nowych technik, zadań czy materiałów i wymusza niejako ciąła pracę nad swoimi umiejętnościami językowymi (por. Dam, 2002; Komorowska, 2003; Pawlak i in., 2006).

Z drugiej jednak strony, promowanie postaw i zachowań autonomicznych napotyka na wiele problemów w naszym kontekście edukacyjnym, co jest zapewne jedną z podstawowych przyczyn, dla których tego typu działania podejmowane sa stosunkowo rzadko i mają dosyć ograniczony charakter. Po pierwsze, wątpliwości co do zasadności rozwijania autonomii maja sami nauczyciele, ponieważ taka decyzja oznacza rezygnacje z jakieś części kontroli nad tym, co dzieje się podczas lekcji i utrudnia ewaluację postępów uczniów. W nieunikniony sposób skutkuje też większym obciążeniem i odpowiedzialnością, ponieważ nie wystarczy już tylko korzystanie z podręcznika, uczący się mogą częściej prosić o indywidualne konsultacje, na które trudno znaleźć czas podczas zajęć, i mogą się pojawić pytania, na które nauczyciel nie zawsze zna odpowiedź. Przeciwni przejmowaniu odpowiedzialności za własną naukę są też często sami uczniowie, czy to dlatego, że są przywiązani do tradycyjnego modelu edukacji, zdają sobie sprawę, że większa samodzielność niesie ze sobą poważne konsekwencje, a może po prostu brak im jest odpowiedniej motywacji do nauki danego języka. Trzeba również wziąć pod uwagę opinię rodziców, którzy, często przez pryzmat własnych doświadczeń, mogą interpretować działania na rzecz autonomizacji jako wyraz niekompetencji nauczyciela czy też pokusy do pójścia po najmniejszej linii oporu, bo przecież rozpowszechnione jest przekonanie, że za wyniki w nauce odpowiada tylko i wyłącznie on, a nie uczeń. Decydujące znaczenie mają też bardzo często obowiązujące przepisy i wymagania, które powoduja, że priorytetem staje się realizacja programu nauczania i 
przygotowanie uczniów do egzaminów, a autonomizacja jest postrzegana jako proces, który może utrudnić realizację tych celów (por. Komorowska, 2003; Pawlak, 2004; Pawlak i in., 2006).

Biorąc pod uwagę omówione powyżej zalety autonomii w nauce języka, problemy tego typu z pewnością nie usprawiedliwiają zaniechania podejmowania działań w tym zakresie, ale powinny nam uzmysłowić, jak ważne jest wyznaczanie realistycznych celów w stymulowaniu postaw i zachowań o charakterze autonomicznym, jak również wzięcie pod uwagę specyfiki danej grupy uczniów. Z jednej strony jest bowiem rzeczą oczywista, że pełna autonomia, czyli ta, którą Littlewood (1999) określa mianem autonomii proaktywnej, nie jest w zasadzie możliwa do osiąnnięcia w warunkach szkolnych, być może za wyjątkiem kilku wybitnych uczniów, których może w trakcie swojej pracy zawodowej spotkać nauczyciel. Z drugiej strony natomiast, nawet w przypadku realizacji o wiele skromniejszego celu, jakim jest stworzenie możliwości rozwoju autonomii reaktywnej, podejmowane działania musza uwzględniać szereg zmiennych indywidualnych, gdyż w innym razie mogą się one zakończyć całkowitym fiaskiem lub ich efektywność będzie bardzo ograniczona. Chodzi tutaj o różnego rodzaju czynniki kognitywne (np. wiek, wrodzone zdolności językowe, style poznawcze, style i strategie uczenia się), czynniki afektywne (np. motywacja, osobowość, lęk językowy, samoocena), czynniki społeczne (np. przekonania, wsparcie ze strony rodziców, sytuacja w domu), pewne deficyty i związane z nimi trudności w uczeniu się (np. dysleksja, problemy ze wzrokiem lub słuchem itp.), a także o poziom opanowania języka docelowego, który stanowi główny przedmiot zainteresowania niniejszych rozważań. Trudno się przecież nie zgodzić, że rozwijanie autonomii musi odbywać się w zupełnie inny sposób w przypadku małych dzieci i dorosłych, dominujące style uczenia się mogą utrudnić lub ułatwić stosowanie określonych technik, przekonania i oczekiwania co do sposobu prowadzenia lekcji będą miały kluczowe znaczenie, jeśli chodzi o stosunek uczniów do autonomizacji, a w przypadku dyslektyków czy uczących się wykazujących objawy zespołu nadpobudliwości wykonywanie pewnych zadań może być utrudnione i wymagać większego zaangażowania i przygotowania nauczyciela. Ogromne znaczenie ma także dostosowanie sposobów stymulowania postaw i zachowań autonomicznych do poziomu zaawansowania uczniów, tym bardziej, że najczęściej istnieją daleko idące różnice w tym zakresie w obrębie tej samej grupy. Jest bowiem rzeczą oczywistą, że w przypadku lepszych uczniów możliwe będzie stosowanie o wiele szerszego repertuaru technik i zadań oraz częstsze odwoływanie się do języka obcego aniżeli w przypadku uczniów słabszych, a ci drudzy będą wymagali o wiele większego wsparcia i większej motywacji. To właśnie temu ważnemu zagadnieniu poświęcona będzie kolejna część publikacji.

\section{Techniki rozwijania autonomii na różnych poziomach zaawansowania}


Celem tej części artykułu jest zilustrowanie możliwości zróżnicowania sposobów rozwijania autonomii w zależności od stopnia opanowania języka docelowego, zarówno w przypadku różnych grup uczniowskich, jak i w obrębie tej samej grupy, w której znaleźć można uczniów bardzo dobrych i zdecydowanie słabszych. Głównym punktem odniesienia będzie tutaj nieco zmodyfikowana lista technik służących stymulowaniu postaw i zachowań autonomicznych, którą zaproponowali Pawlak i in. (2006), przy czym w każdym przypadku przedstawione zostaną rozwiązania, które można wykorzystać w pracy z lepszymi i słabszymi uczniami.

\section{Organizacja lekecii i dobór materiatón}

Bardziej zaawansowani uczniowie mogą zostać zaangażowani w prowadzenie niektórych lekcji poprzez przygotowywanie prezentacji na interesujące tematy, niekoniecznie związane z tokiem lekcji, podawanie wyjaśnień gramatycznych i wprowadzanie słownictwa. Moga także wyszukiwać dodatkowe materiały będące uzupełnieniem podręcznika lub opracowywać ćwiczenia powtórzeniowe (gramatyka, słownictwo) dla swoich nieco mniej zaawansowanych kolegów i koleżanek. Istnieje też możliwość takiej organizacji zajęć, aby mogli oni pomagać uczniom słabszym w rozwiązywaniu problemów w nauce języka obcego, na przykład poprzez poświęconą realizacji tego celu pracę $\mathrm{w}$ parach i małych grupach. Uczniowie słabsi natomiast mogliby mieć możliwość współdecydowania o tym, co warto byłoby powtórzyć i dodatkowo przećwiczyć. Mogą też zostać poproszeni o wyszukiwanie informacji dotyczacych omawianych tematów, tak w języku ojczystym, jak i języku docelowym.

\section{Podnoszenie śniadomości uczacych sie}

Zarówno lepsi, jak i słabsi uczniowie moga zostać poproszeni o wypełnienie kwestionariuszy dotyczących przekonań, stylów uczenia się bądź też ulubionych sposobów nauki, przy czym można tutaj wykorzystać zarówno język polski, jak i język obcy, w zależności od poziomu zaawansowania. Jednym z narzędzi, które mogłoby być przydatne w tym celu jest na pewno odpowiednia wersja Europejskiego porffolio jesyykowego, a szczególnie Biografia jezyłkowa. I tak na przykład w Europejskim portfolio jezylkowym dla uczniów szkót ponadgimnazjalnych i studentón (Bartczak i in., 2006) znaleźć można stwierdzenia dotyczące różnych aspektów nauki języków obcych, które mają zachęcać użytkowników do refleksji w tym zakresie, takie jak: „Znajomość języków obcych jest niezbędna w dzisiejszych czasach”, „Znajomość gramatyki nie jest istotna w komunikacji”, „Wolę, żeby nauczyciel poprawiał wszystkie moje błędy”, „Nauczyciel powinien cały czas używać j. obcego podczas lekcji”, „Potrzebne sa specjalne predyspozycje do nauki języka obcego" itp. Można też odwołać się do instrumentów, które są wykorzystywane w różnego rodzaju projektach badawczych, choć większość z nich dostępna jest w wersji anglojęzycznej i konieczne będzie ich przełożenie na 
język polski. Dobrymi przykładami takich narzędzi są: inwentarz. prz̨ekonań o nauce jezyka (ang. Beliefs about Language Learning Inventory, BALLI) (Horwitz, 1988), ankieta stużqca okeréleniu poziomu leku jezykowego (ang. Foreign Language Classroom Anxiety Scale, FLACS) (Horwitz, Horwitz i Cope, 1986), kwestionariusz stużacy określeniu stylów uczenia sie (Perceptual Learning Style Preference Questionnaire) (Reid 1987) oraz różne instrumenty pozwalające na określenie poziomu i rodzaju motywacji. Wypełnienie takich kwestionariuszy może stanowić punkt wyjścia do omówienia i przedyskutowania udzielonych odpowiedzi, na przykład w grupach na tym samym, a później na różnym poziomie i w końcu na forum całej klasy. Można też poprosić lepszych i słabszych uczniów o wymianę doświadczeń na temat nauki języka i wzajemne udzielanie sobie wskazówek i porad, a często przydatna będzie również dyskusja ze wszystkimi uczniami dotycząca ich przekonań, ulubionych sposobów nauki i wykorzystywanych materiałów, prowadzona w obu językach. Warto także sięgnąć po zadania mające na celu stymulowanie refleksji, takie jak te zamieszczone w przewodnikach metodycznych towarzyszacych polskim wersjom Europejskiego portfolio jezy/kowego, gdyż moga one być z powodzeniem wykonywane przez uczniów na bardzo różnych poziomach. Przykłady dwóch takich zadań podane są poniżej (por. Pawlak i in., 2006: 91, 97):

\section{TWORZENIE PROFILU DOBREGO UCZNIA}

Uczniowie najpiem pracuja indywidualnie $i$ sporzqdzaja liste dziesieciu cech $i$ zachowan, k.tóre ich zdaniem charakteryzuja osoby odnosqque sukeces w nauce jezyka. Potem porównuja swoja liste z partnerem $i w$ drodze negocjacji wybieraja pię́ takich atrybutów. Nastepnie pracuja z. kolejnymi osobami $i$ za każdym razem staraja sie ustalic piéc wspólnych elementów. Po zakończeniu zadania uczniowie zapisuja na tablicy ten swego rodzaju profil dobrego ucznia i wspólnie z. nauczycielem zastanawiaja sie nad waga poszczególnych cech $i$ zachowań.

\section{REFLEKSJA NAD CELAMI I EFEKT AMI LEKCJI}

Pod koniec lekcii nauczyciel prosi uczniów, aby wypisali tray rzeczy, których sie w jej trakcie nauczyli. Następnie zapisuje na tablicy cele, które chciat osiagnać i prosi o chwile refleksji $i$ identyfikacje ewentualnych różnic. Kilku uczacych sie jest w końcu poproszonych o próbe uzasadnienia swoich wyborów $i$ określenie, na ile cele wyznaczone przez prowadzqcego miaty dla nich znaczenie.

\section{Trening strategiczny}

Z uwagi na fakt, że stosowanie odpowiednio dobranych do własnych preferencji i wymogów wykonywanego zadania strategii uczenia się jest uważane za klucz do autonomii (Wenden, 1991), konieczne jest prowadzenie treningu strategicznego, który powinien odbywać się przy uwzględnieniu kilku podstawowych zasad, tj.: (1) punktem wyjścia powinna być identyfikacja strategii stosowanych przez uczniów, (2) na początku główny nacisk powinien być położony na strategie metakognitywne, (3) uczący się powinni być w pełni 
świadomi celów treningu, (4) strategie powinny być prezentowane i ćwiczone podczas wykonywania konkretnych zadań językowych, oraz (5) na tyle, na ile jest to możliwe, trening powinien zaczynać się wcześnie, być wszechstronny i intensywny (patrz Droździał-Szelest, 1997; Chamot, 2004; Pawlak i in., 2006). Choć przestrzeganie wszystkich tych zaleceń ma ogromne znaczenie, nie mniej ważne jest zróżnicowanie celów i metod zależnie od poziomu uczniów, a także indywidualizacja podejmowanych działań, tak aby uwzględnić ich potrzeby, preferencje i style poznawcze. Niezależnie od stopnia opanowania języka, pierwszym krokiem powinno być zapoznanie uczniów z inwentarzami strategii uczenia się, najlepiej w języku polskim, ponieważ pozwoli im to uświadomić sobie, w jaki sposób się uczą i jakie inne działania strategiczne mogliby podejmować. Można w tym celu wykorzystać Europejskie portoflio jezylkowe dla uczniów szkoól ponadgimnazjalnych $i$ studentów, w którym w sekcji zatytułowanej Jak ucze sie jezyków (Bartczak i in., 2006: 21-26) zamieszczono listy strategii przydatnych w nauce sprawności i podsystemów języka i znaleźć tam można takie stwierdzenia jak: „Buduję skojarzenia, aby łatwiej zapamiętać nowe słówka”, „Staram się zrozumieć każdą regułę gramatyczną”, ,Znam transkrypcję fonetyczną i sprawdzam wymowę w słowniku”, „Słucham wiadomości radiowych w języku obcym”, „Robię notatki, aby lepiej zrozumieć treść tekstu”, „Szukam okazji do rozmowy w języku obcym”, „Zbieram materiał językowy przydatny do napisania tekstu" itp. Podobnie jak w przypadku podnoszenia świadomości uczących się, można też sięgnąć po gotowe inwentarze strategii, nie tylko dobrze znany i często stosowany inwentarz strategii uczenia sie jezylka obcego (ang. Strategy Inventory for Language Learning, SILL) (Oxford, 1990), ale także nowsze narzędzia, których przykładem może być skala umiejętności autoregulacji $w$ uczeniu sie stownictwa (Self-Regulating Capacity in Vocabulary Learning Scale, SRCvoc) (Tseng, Dörnyei i Schmitt, 2006). Lepsi i słabsi uczniowie mogą następnie wspólnie wykonywać zadania językowe, które poprzedza i po których następuje dyskusja na temat stosowanych strategii, a przydatna będzie też dyskusja w grupach lub na forum klasy, w języku polskim bądź obcym, na temat stosowanych strategii i ich przydatności. Także tutaj warto sięgnąć po zadania, które maja na celu bardziej efektywne wykorzystywanie działań o charakterze strategicznym, takich jak to zaprezentowane poniżej (por. Pawlak i in., 2006: 88):

\section{TWORZENIE I STOSOW ANIE ŁAŃCUCHÓW STRATEGII}

Pracujac $w$ grupach, uczniowie maja za zadanie opracowaí zestaw strategii, który by tby pomocny $w$ pracy nad wymowa popręer ogladanie filmów w oryginalnej wersji jezykowej. Opracowane lańcuchy strategii sq nastęnie pręekazywane uczniom w innej grupie, k.tóra proponuje ewentualne zmiany, po czym projekt wraca do jego twórców, którzy decyduja jakie uprowadzic w nim modyfikacje. W ramach zadania domowego uczniowie ogladaja film na DVD stosujac opracowany pręez siebie zestaw strategii i praygotowuja sprawozdania, które sa podstawa do dyskusji podczas kolejnych zajeć. 
Zróżnicowanie zadań domowych

Zadania domowe dają wiele możliwości stymulowania postaw i zachowań autonomicznych, przy czym stosunkowo prosto jest w tym przypadku dostosować podejmowane działania do różnych poziomów zaawansowania i możliwości uczniów. Można tu wymienić negocjowanie ilości, rodzaju i terminu pracy domowej dla lepszych i słabszych uczniów, proponowanie różnych, bardziej lub mniej wymagających tematów wypracowań i różnicowanie zakresu udzielanego wsparcia, na przykład poprzez podawanie niezbędnego słownictwa, tekstów modelowych itp. Nic nie stoi na przeszkodzie, aby, zależenie od poziomu zaawansowania, uczniowie byli proszeni o wykonywanie różnych ćwiczeń i zadań (np. ćwiczenia gramatyczne i leksykalne, prezentacje). Warto też rozważyć możliwości dalszej indywidualizacji w obrębie obu tych grup, a także stworzenie warunków do wspólnego wykonywania i korekty zadań domowych przez uczniów na różnych poziomach zaawansowania.

\section{Zachęcanie ucznión do prowadzenia dziennika}

Mimo że jest to jedna $\mathrm{z}$ najtrudniejszych technik służących rozwijaniu autonomii, głównie dlatego, że uczniowie są często niechętni prowadzeniu dzienników, rzadko robią to z własnej woli i nie dokonują wpisów regularnie, to również tutaj istnieje możliwość uwzględnienia różnych poziomów zaawansowania. Uczący się mogą mieć bowiem wybór co do tematyki i zakresu wpisów oraz języka, w którym odnotowują swoje refleksje i przemyślenia, ponieważ to oni sami są najlepiej w stanie określić swoje umiejętności i zdecydować, co potrafia, a czego nie są w stanie zrobić. Prowadzone dzienniki mogą też stanowić podstawę do dialogu między lepszymi i słabszymi uczniami, czy to w ramach pracy w parach w klasie, czy też jako część zadania domowego, co na pewno przyczyni się do refleksji nad procesem uczenia się i może ułatwić skuteczniejsze radzenie sobie z napotykanymi problemami.

\section{Praca w parach i malych grupach oraz wykonywanie zadan projektowych}

Praca w parach i małych grupach i wykonywanie zadań projektowych to niezwykle ważne techniki w rozwijaniu autonomii, gdyż umożliwiają one uczniom samodzielne podejmowanie decyzji co do sposobu wykonania określonego zadania, a jednocześnie stwarzają możliwości indywidualizacji, również pod kątem uwzględniania różnych poziomów zaawansowania. I tak dla przykładu, dobrym rozwiązaniem jest różnicowanie rodzajów zadań wykonywanych przez lepszych i słabszych uczniów, albo w całości, albo w części (np. inne teksty lub różne polecenia do tego samego tekstu), dostosowywanie czasu przeznaczonego na zaplanowanie zadania oraz udzielanego wsparcia do umiejętności uczących się, czy dokonywanie modyfikacji w składzie poszczególnych grup, tak aby uczniowie mogli pracować zarówno z osobami na swoim poziomie, jak i z lepszymi i słabszymi. Jeśli chodzi o zadania projektowe, doskonałą strategia jest tworzenie grup składających się z 
uczniów na różnych poziomach zaawansowania i przydzielanie lepszym i słabszym uczniom różnych ról podczas planowania, wykonywania i prezentacji rezultatów projektu.

\section{Kontrakty indywidualne i grupowe}

Poza tym, że kontrakty tego typu przyczyniają się do autonomizacji, to w naturalny sposób dają one nauczycielowi sposobność uwzględnienia różnych umiejętności uczących się. Można bowiem wynegocjować odmienne cele, harmonogramy, sposoby oraz oczekiwane rezultaty nauki dla różnych grup uczniów, ale także dla poszczególnych osób, co jest bardzo ważne w sytuacji, gdy mamy do czynienia z jednym czy dwoma uczniami wyróżniającymi się na tle całej klasy, czy to z uwagi na bardzo wysoki, czy też bardzo niski poziom opanowania języka.

\section{Indywidualizacja zadań podczas lekecji}

Choć konieczność realizacji programu może być tutaj pewną przeszkodac to podczas jednej lekcji w tygodniu, a przynajmniej jej części, uczniowie moga mieć możliwość samodzielnego decydowania, nad czym chcieliby pracować (np. czytanie, słownictwo, pisanie, kultura itp.). Jest to oczywiście ogromna szansa dla uczniów na różnych poziomach zaawansowania, aby skoncentrować się na tym, co ich najbardziej interesuje bądź też na zagadnieniach, z którymi mają największe problemy, przy czym kluczowe będzie tutaj wsparcie nauczyciela, a także współpraca pomiędzy lepszymi i słabszymi uczniami. Warto również podkreślić, że najlepsi uczący się moga w takich sytuacjach wykonywać zadania, które nie są bezpośrednio związane z programem nauczania i celami lekcji, co przyczynia się do ograniczenia frustracji i nudy, tak często prowadzących do problemów z dyscyplina.

\section{Zachecanie do korzystania z technologii komputerowej}

Szeroko dostępna technologia komputerowa i informacyjna stwarza ogromne możliwości stymulowania autonomii uczniów, a przy tym pozwala na uwzględnienie różnic w poziomie opanowania języka docelowego. Warto tu wspomnieć o zapoznawaniu słabszych i lepszych uczniów z programami czy też stronami internetowymi, które mogą wspomagać naukę, a jednocześnie sa odpowiednie dla ich umiejętności językowych lub mogą łatwo do nich zostać dostosowane. Innym rozwiązaniem jest wykonywanie projektów interdyscyplinarnych przy użyciu technologii, co wiąże się z odpowiednim podziałem ról, o którym już wspomniano powyżej, czy zapoznawanie uczniów z ogromnym potencjałem słowników elektronicznych i korpusów, z pozostawianiem im decyzji co do wyboru i sposobu korzystania z tego typu zasobów.

\section{Zachecanie do kontaktu zjezykiem pora klasa}


Uświadamiając uczniom konieczność kontaktu z przyswajanym językiem obcym poza klasą, nauczyciel ma możliwość wskazania takich rozwiązań, które będa najbardziej odpowiednie dla danej grupy. O ile lepszym uczniom można polecić obcojęzyczne strony internetowe, rozmowy przez komunikatory internetowe czy czytanie czasopism i ksiązek w oryginale, to uczniowie słabsi na pewno skorzystają na czytaniu uproszczonych wersji książek i czasopism dla osób uczących się języka obcego, czy używaniu specjalnie dla nich przeznaczonych portali internetowych. Zwiększanie kontaktu z językiem poza klasą można także osiagnąć przez zadania domowe, które takiego kontaktu będą wymagać, a rozwiązania w tym zakresie zostały już omówione powyżej. 
Rozwijanie umiejętności samooceny $i$ oceny wrajemnej

Umiejętność samodzielnej oceny własnych postępów ma kluczowe znaczenie w promowaniu postaw i zachowań o charakterze autonomicznym, bo bez niej niemożliwe jest w zasadzie wyznaczanie odpowiednich celów, dobór optymalnych strategii oraz monitorowanie samego przebiegu nauki. Można w tym celu wykorzystać zadania, sekcje powtórzeniowe i listy umiejętności zamieszczone w wielu podręcznikach, ale także tabele samooceny i listy umiejętności zawarte w polskich wersjach Europejskiego portfolio jezykowego dla różnych grup wiekowych. Kluczowe znaczenie będzie miało tutaj dostosowanie tego typu narzędzi do poziomu zaawansowania uczniów oraz pomoc, jakiej lepsi uczniowie mogą udzielić uczniom słabszym monitorując ich produkcję językową bądź też wspomagając ich w identyfikacji istniejących problemów i rzetelnym określaniu mocnych i słabszych stron.

\section{Przyszłość autonomii w dydaktyce języków obcych}

Podsumowując powyższe rozważania, trzeba jednoznacznie stwierdzić, ̇̇e pomimo obecnych problemów i trudności na pewno warto podejmować działania zmierzające do rozwijania autonomii, głównie dlatego, że bez tego atrybutu uczącym się trudno będzie osiągnąć sukces w nauce języka obcego, niezależnie od tego, jak ten sukces definiuja. Nie mniej ważne jest to, że zachęcanie uczniów do przejmowania odpowiedzialności za własną naukę i stwarzanie im tego typu możliwości to bardzo dobry sposób na uwzględnienie indywidualnych potrzeb edukacyjnych, czy to w odniesieniu do wymienionych w niniejszej publikacji zmiennych indywidualnych, czy też efektywnej pracy z uczniami na różnych poziomach zaawansowania. Wydaje się bowiem, że to właśnie pewna doza autonomii może być lekarstwem na to, iż w zdecydowanej większości przypadków w tej samej klasie znajdują się uczniowie legitymujący się bardzo różną znajomością języka obcego, jako że działania mające na celu jej rozwijanie dają liczne możliwości skutecznego radzenia sobie $z$ takimi dysproporcjami. Z drugiej jednak strony, nauczyciele muszą wykazać się daleko idącym realizmem, a to dlatego, że w różnych szkołach, klasach i grupach uczniowskich szanse na skuteczne rozwijanie autonomii będą się bardzo różnić, a nazbyt ambitne cele i nieadekwatne działania moga łatwo doprowadzić do chaosu, a wtedy trudno będzie mówić o jakichkolwiek zaletach samodzielności uczących się. W związku z tym trzeba sobie uświadomić, że głównym celem w warunkach szkolnych, może za wyjątkiem jednostek wybitnych, jest stymulowanie autonomii reaktywnej, określanej też mianem pólautonomii (Dickinson, 1987), przy czym również tutaj mamy do czynienia z różnymi jej poziomami, które muszą uwzględniać istniejące realia i ograniczenia. Kluczowe znaczenie ma również to, że techniki i zadania mające na celu stymulowanie autonomii muszą uwzględniać specyfikę uczniów, rozumianą jako istniejące pośród nich różnice indywidualne, ale także często odmienne umiejętności 
językowe. Innymi słowy skuteczność autonomizacji jest w dużej mierze funkcją stopnia, w jakim nauczyciele dostosują podejmowane działania do możliwości lepszych i słabszych uczniów, stosując niektóre z rozwiązań, które zostały zaproponowane w niniejszym artykule. Aby tak się jednak stało, sami nauczyciele muszą być autonomiczni i samodzielni, bo chociaż autonomia nauczyciela nie jest gwarancją autonomii ucznia, to jest ona niezbędnym warunkiem dla efektywnego promowania postaw i zachowań o charakterze autonomicznym, uwzględniając przy tym indywidualne potrzeby i możliwości każdego ucznia.

\section{BIBLIOGRAFIA}

Bartczak, E, Lis, Z, Marciniak, I. i Pawlak, M. 2006. Europejskie portfolio jezykowe dla uczniów sqkót ponadgimnazjalnych i studentów. Warszawa: Centralny Ośrodek Doskonalenia Nauczycieli.

Benson, P. 2001. Teaching and researching autonomy. Harlow: Pearson Education.

Benson, P. 2007. „Autonomy in language teaching and learning”. [w:] Language Teaching 40: 21-40.

Benson, P. i Voller, P. 1997. „Introduction: Autonomy and independence in language learning", [w:] Benson, P. i Voller, P. (red.). Autonomy and independence in language learning. London and New York: Longman. 18-34.

Bielska, J. 2008. „Autonomia ucznia - wyzwanie czy udręka dla młodego nauczyciela". [w:] Pawlak, M. (red.). Autonomia w nauce jezylea obcego - co osiagnelismy i dokad zmierzamy. Poznań - Kalisz - Konin: Wydawnictwo UAM i PWSZ w Koninie. 173-185.

Boud, D. 1988. „Moving towards autonomy”. [w:] Boud, D. (red.). Developing student autonomy in learning. (wydanie drugie). London: Kogan Page Ltd. 17-39.

Chamot, A. U. 2004. „Issues in language learning strategy research and training". [w:] Electronic Journal of Foreign Language Teaching 1: 14-26.

Dam, L. 2002. „Developing learner autonomy - preparing learners for lifelong learning". [w:] Pulverness, A. (red.). LATEFL 2002: York Conference Selections. Whitstable, Kent: IATEFL. 41-52.

Dickinson, L. 1987. Self-instruction in language learning. Cambridge: Cambridge University Press.

Droździał-Szelest, K. 2008. „Trening strategiczny na lekcji języka obcego - mit czy rzeczywistość” [w:] Pawlak, M. (red.). Autonomia w nauce jezyka obcego co osiagnelismy i dokad zmierzamy. Poznań - Kalisz - Konin: Wydawnictwo UAM i PWSZ w Koninie. 405-415.

Droździał-Szelest, K. 1997. Language learning strategies in the process of acquiring a foreign language. Poznań: Motivex.

Głowacka, B. 2008. „O ograniczeniach w kształtowaniu umiejętności samodzielnego uczenia się na lekcji języka obcego w gimnazjum prezentacja wybranych aspektów badania ankietowego" [w:] Pawlak, M. (red.). Autonomia w nauce jezykea obcego - co osiagnelismy $i$ dokad zmierzamy. 
Poznań - Kalisz - Konin: Wydawnictwo UAM i PWSZ w Koninie. 159172.

Illich, I. 1971. Deschooling society. London: Kalder and Boyars.

Harmer, J. 2001. The practice of English language teaching. (wydanie trzecie). Harlow: Pearson Education.

Hedge, T. 2000. Teaching and learning in the language classroom. Oxford: Oxford University Press.

Holec, H. 1981. Autonomy in foreign language learning. Strasbourg: Council of Europe.

Horwitz, E. K. 1988. „The beliefs about language learning of beginning university foreign language students”. [w:] Modern Language Journal 72: 283-294.

Horwitz, E. K., Horwitz, M. B. i Cope, J. 1986. „Foreign language classroom anxiety". Modern Language Journal 70: 125-132.

Hurd, S. i Murphy, L. (red.). 2005. Success with languages. London: Routledge.

Komorowska, H. 2003. Metodyka nauczania jezyków obych. Warszawa: Fraszka Edukacyjna.

Kumaravadivelu, B. 2003. Beyond methods: Macrostrategies for language teaching. New Haven: Yale University Press.

Lamb, T. E. i Reinders, H. (red.). 2007. Learner and teacher autonomy: Concepts, realities and responses. Amsterdam: John Benjamins.

Legutke, M. i Thomas, H. 1991. Process and experience in the language classroom. London and New York: Longman.

Little, D. 1991. Learner autonomy 1: Definitions, issues and problems. Dublin: Authentik.

Littlewood, W. 1999. „Defining and developing autonomy in East Asian countries". [w:] Applied Linguistics 20: 71-94.

Oxford, R. 1999. Language learning strategies: What every teacher should know. New York: Newbury House.

Pawlak, M. (red.). 2004. Autonomia w nauce jezylka obcego. Poznań - Kalisz: Wydawnictwo UAM.

Pawlak, M. (red.). 2008a. Autonomia w nauce jezykea obcego - co osiagnelismy $i$ dokad zmierzamy. Poznań - Kalisz - Konin: Wydawnictwo UAM i PWSZ w Koninie.

Pawlak, M. 2008b. „Autonomia na lekcjach języka angielskiego w liceum diagnoza, analiza, wnioski". [w:] Pawlak, M. (red.). Autonomia w nauce jezyke a obego - co osiagnelismy $i$ dokeqd zmierzamy. Poznań - Kalisz - Konin: Wydawnictwo UAM i PWSZ w Koninie. 137-157.

Pawlak, M. 2008c. „Europejskie portfolio jezykowe jako narzędzie rozwijania autonomii wśród studentów anglistyki - wyniki badań". [w:] Jezyyki Obce w Szkole 6/2008. 127-138.

Pawlak, M. (red.). (w druku). Autonomia w nauce jezylka obcego - uczeń a nauczyciel. Poznań - Kalisz - Konin: Wydawnictwo UAM i PWSZ w Koninie.

Pawlak, M., Marciniak, I., Lis, Z. i Bartczak, E. 2006. Jak samodzielnie poznawaí jezyki i kultury. Przewodnik metodyczny do Europejskiego portfolio jezylkowego dla 
uczniów szkót ponadgimnazjalnych i studentów. Warszawa: Centralny Ośrodek Doskonalenia Nauczycieli.

Pembertson, R., Toogood, S. i Barfield, A. (red.). 2010. Maintaining control: Autonomy and language learning. Hong Kong: Hong Kong University Press.

Reid, J. M. 1987. „The learning style preferences of ESL students”. [w:] TESOL Quarterly 21: 87-111.

Rogers, C. 1969. Freedom to learn. Columbus, OH: Charles E. Merrill.

Scharle, Á. i Schabó, A. 2000. Learner autonomy: A guide to developing learner responsibility. Cambridge: Cambridge University Press.

Tseng, W., Dörnyei, Z. i Schmitt, N. 2006. „A new approach to assessing strategic learning: The case for self-regulation in vocabulary acquisition". [w:] Applied Linguistics 27: 78-102.

Wenden, A. 1991. Learner startegies for learner autosomy. London: Prentice Hall.

Wilczyńska, W. 1999. Uczyć sie czy być nauczanym? O autonomii w przyswajaniu jezyka a obcego. Warszawa: Wydawnictwo Naukowe PWN.

Wilczyńska, W. (red.). 2002. Autonomizacja w dydaktyce jezyłoów obcych. Doskonalenie sie w komunikacii ustnej. Wydawnictwo UAM. 